\title{
Primary HIV-I infection during pregnancy: high rate of HIV-I MTCT in a cohort of patients in southern Brazil
} Karin Nielsen-Saines*1, Marineide Melo², Ivana Varella², Rosana Fonseca², Rita Lira ${ }^{2}$, Maria Lourdes Turella ${ }^{2}$, Ivete Canti ${ }^{2}$, Claudio Campello ${ }^{2}$, Ana Maria Moreira ${ }^{2}$ and Breno Riegel Santos ${ }^{2}$

\author{
Address: ${ }^{1}$ Department of Pediatrics/ Infectious Diseases, David Geffen UCLA School of Medicine, Los Angeles, CA 90095, USA and ${ }^{2}$ Department \\ of Infectious Diseases. Grupo Hospitalar Conceiçao, Porto Alegre, Brazil \\ * Corresponding author
}

from Fourth Dominique Dormont International Conference. Host-Pathogen Interactions in Chronic Infections

Paris, France. 13-15 December 2007

Published: 9 April 2008

Retrovirology 2008, 5(Suppl I):OI doi:I0.II86/1742-4690-5-SI-OI

This abstract is available from: http://www.retrovirology.com/content/5/SI/OI

(c) 2008 Nielsen-Saines et al.; licensee BioMed Central Ltd.

\section{Background}

Mother to Child HIV-1 Transmission (MTCT) is infrequent among women who receive highly active antiretroviral therapy (HAART) throughout pregnancy [1]. Women who undergo primary HIV-1 infection during pregnancy, however are at high risk of perinatal transmission [2].

\section{Materials and methods}

MTCT rates among patients receiving antenatal HAART at our institution were evaluated and compared to MTCT rates among women identified as HIV-1 infected late in pregnancy including women who became HIV-1 seropositive during gestation. Rapid HIV testing of pregnant women was performed on all women admitted in labor to our institution who had negative HIV results $>3$ months prior or with unknown HIV-1 serostatus. Neonatal infection was ascertained using RNA and DNA PCR at several time points.

\section{Results}

Over two years, deliveries at our institution totalled 11,241 with 318 (2.9\%) occurring in HIV-1 infected women. The incidence of HIV-1 seroconversion was 0.8 / 1,000 (CI 95\% 0.4-1.5/1,000). The study population consisted of 256 HIV+ women who delivered at our institution having received prenatal care at our hospital and HAART during pregnancy or were identified as HIVinfected at delivery. Of these, 212 women had infants with known HIV outcomes. To 168 women on HAART, 142 infants $(84 \%)$ had diagnosis ascertained: 1 child was HIV-infected (0.6\%). Of the remaining, 6 (3.6\%) deaths occurred in the neonatal period; $5(3.0 \%)$ women miscarried and $15(8.9 \%)$ infants were lost to follow-up. Eightyeight women received no antiretroviral treatment being identified as HIV-1 infected at delivery. Infant diagnosis was ascertained in 70 cases. For the remainder, $4(4.4 \%)$ neonatal deaths occurred before diagnosis, 7 (8.0\%) women miscarried and $7(8.0 \%)$ infants were lost to follow-up. Of these, 61 had unknown HIV-1 seroconversion time and 9 had proven seroconversion during pregnancy. In women with no treatment and unknown seroconversion time, there were 5/61 transmissions (8.2\%) and in those with proven seroconversion 3/9 (33\%). No women breastfed.

\section{Conclusions}

In southern Brazil, an area of high HIV-1 prevalence, seroconversion during pregnancy is not an unusual phenomenon and is associated with extremely high HIV-1 MTCT rates. Strategies should be implemented for repeat testing of patients later in pregnancy in addition to testing of partners early in pregnancy in order to identify patients at risk of seroconversion. 


\section{References}

I. Calvet GA, João E, Nielsen-Saines K, et al:: Trends in characteristics and management of HIV-infected pregnant women over a nine-year period: a prospective cohort study in Rio de Janeiro, Brazil. Revista Brasileira de Epidemiologia 2007, I0(3):323-37.

2. Fiscus SA, Pilcher CD, Miller WC, et al:: Rapid, real-time detection of acute HIV infection in patients in Africa. J Infect Dis 2007, 195(3):416-24.

Publish with Bio Med Central and every scientist can read your work free of charge

"BioMed Central will be the most significant development for disseminating the results of biomedical research in our lifetime. " Sir Paul Nurse, Cancer Research UK

Your research papers will be:

- available free of charge to the entire biomedical community

- peer reviewed and published immediately upon acceptance

- cited in PubMed and archived on PubMed Central

- yours - you keep the copyright

Submit your manuscript here:

http://www.biomedcentral.com/info/publishing_adv.asp 